\title{
ANALISIS REGRESI DATA PANEL PADA KINERJA PERBANKAN DI INDONESIA
}

\author{
Keti Purnamasari \\ Jurusan Administrasi Bisnis, Politeknik Negeri Sriwijaya \\ Email: keti.purnamasari@polsri.ac.id
}

\begin{abstract}
The determinants of bank performance can be grouped into three groups, namely; 1) bank specific factors related to management decisions and policy objectives, 2) industry factors related to industrial structure and market growth, and 3) macroeconomic factors that reflect the economic conditions in which the bank operates. This study analyzes the effect of bank-specific factors and industry factors on banking performance using panel data regression analysis on a sample of 39 Indonesian Commercial Banks during the 2015-2019 period. Bank specific factors consist of bank size, efficiency, and capital adequacy, while the industrial factor in this study is the market structure which includes market concentration and market share. Banking performance is measured by Return on Equity and Net Interest Margin. The results of this study indicate that bank size and efficiency (BOPO) has a negative and significant effect on banking performance. Capital adequacy and market concentration have no effect on banking performance. Meanwhile, the market share variable has a positive and significant effect on banking performance as measured by Net Interest Margin but does not affect banking performance as measured by Return on Equity.
\end{abstract}

Keywords: bank size, efficiency, capital adequacy, market structure, banking performance

\begin{abstract}
Abstrak: Determinan kinerja bank dapat dikelompokkan menjadi tiga kelompok yaitu ; 1) faktor spesifik bank yang terkait dengan keputusan manajemen dan tujuan kebijakan, 2) faktor industri yang terkait struktur industri dan pertumbuhan pasar, dan 3) faktor makroekonomi yang mencerminkan keadaan ekonomi dimana bank beroperasi. Penelitian ini menganalisis pengaruh faktor spesifik bank dan faktor industri terhadap kinerja perbankan dengan menggunakan analisis regresi data panel pada sampel dari 39 Bank Umum Konvensional Indonesia selama periode 2015-2019. Faktor spesifik bank terdiri atas ukuran bank, efisiensi, dan kecukupan modal sedangkan faktor industri dalam penelitian ini adalah struktur pasar yang meliputi konsentrasi pasar dan pangsa pasar. Kinerja perbankan diukur dengan Return on Equity dan Net Interest Margin. Hasil penelitian ini menunjukkan hasil bahwa variabel ukuran bank dan efisiensi (BOPO) memiliki pengaruh negatif dan signifikan terhadap kinerja perbankan. Variabel kecukupan modal dan konsentrasi pasar tidak berpengaruh terhadap kinerja perbankan. Sedangkan variabel pangsa pasar memiliki pengaruh positif dan signifikan terhadap kinerja perbankan yang diukur dengan Net Interest Margin namun tidak berpengaruh terhadap kinerja perbankan yang diukur dengan Return on Equity.
\end{abstract}

Kata kunci: ukuran bank, efisiensi, kecukupan modal, struktur pasar, kinerja perbankan

\section{PENDAHULUAN}

Banyak sekali implementasi untuk menilai dan menganalisis kinerja bank terkait dengan mengidentifikasi sumber-sumber operasional yang tidak efisien, kesenjangan alokasi sumber-sumber yang efektif, pengaruh perubahan peraturan perundang-undangan yang berlaku terhadap operasional bank, dan kemampuannya manajer Bank dalam memberdayakan bank untuk mengarahkan bisnis mereka ke arah tren bisnis saat ini, proses bisnis yang menguntungkan, dan lainlain (Paradi \& Zhu, 2013)

Faktor Internal dan eksternal dapat mempengaruhi kelangsungan usaha bank sehingga bank menyusun rencana bisnis strategis dengan menerapkan prinsip kehatihatian, penerapan manajemen risiko, dan azas perbankan yang sehat (OJK, 2019). Hal ini dilakukan karena produktivitas suatu bank merupakan faktor kunci dalam pertumbuhan dan perkembangan ekonomi negara tersebut. Selain kepentingan ekonomi yang tinggi, penilaian kinerja bank juga sangat penting dilakukan dalam rangka peningkatan operasi dan pemantauan kondisi keuangan.

Evaluasi kinerja dianggap sebagai salah satu cara terbaik untuk perbaikan operasional organisasi. Dengan menerapkan berbagai 
metode pengukuran kinerja, organisasi dapat mengevaluasi efektivitas dan efisiensi proses yang relevan dengan tujuan strategis organisasi. Selain itu, alat pengukuran kinerja dapat membantu organisasi mengalokasikan dan mendistribusikan sumber daya dengan cara yang lebih baik (Roghanian et al., 2012).

Determinan kinerja bank dapat dikelompokkan menjadi tiga kelompok yaitu ; 1) faktor spesifik bank yang terkait dengan keputusan manajemen dan tujuan kebijakan, 2) faktor industri yang terkait struktur industri dan pertumbuhan pasar, dan 3) faktor makroekonomi yang mencerminkan keadaan ekonomi dimana bank beroperasi. Variabel karakteristik bank antara lain : ukuran bank, risiko kredit, kualitas aset, efisiensi manajemen, likuiditas, risiko gagal bayar, dan kecukupan modal. Variabel khusus industri termasuk konsentrasi pasar dan pertumbuhan pasar. Variabel makroekonomi yang paling umum digunakan termasuk PDB dan inflasi.

Banyak penelitian yang mencoba menjelaskan kontribusi berbagai variabel terhadap kinerja bank sehingga seringkali peneliti menemukan hasil yang berbedabeda bahkan kontradiktif. Hal ini dijelaskan secara khusus oleh berbagai data yang mereka gunakan, untuk periode dan wilayah yang berbeda. Telah banyak penelitian yang didedikasikan untuk menganalisis kinerja perbankan dengan berfokus pada dampak dari berbagai faktor internal dan eksternal namun memiliki hasil yang berbeda sehingga menarik untuk dilakukan analisis mendalam.

Penelitian ini akan menganalisis pengaruh faktor spesifik bank dan faktor industri terhadap kinerja perbankan dengan menggunakan analisis regresi data panel pada sampel dari 38 Bank Umum Konvensional Indonesia selama periode 2015-2019. Faktor spesifik bank terdiri atas ukuran bank, efisiensi, dan kecukupan modal sedangkan faktor industri dalam penelitian ini adalah struktur pasar yang meliputi konsentrasi pasar dan pangsa pasar. Indikator utama yang digunakan untuk mengukur kinerja perbankan yaitu profitabilitas yang diukur dengan Return on Equity dan Net Interest Margin. Variabelvariabel ini dipilih untuk dianalisis kembali karena masih terdapat perbedaan hasil penelitian di antara peneliti.

Penelitian Haryati \& Widyarti (2016) Hendrawan \& Lestari (2017) dan mendapatkan hasil bahwa ukuran bank berpengaruh positif terhadap kinerja perbankan sedangkan penelitian Thaibah \& Faisal (2020) mendapatkan hasil ukuran bank tidak berpengaruh terhadap kinerja perbankan.

Penelitian Purwoko \& Sudiyanto (2013), penelitianHaryati\& Widyarti(2016), penelitian Stephani et al., (2017) serta penelitian Thaibah \& Faisal (2020) mendapatkan hasil bahwa variabel efisiensi (rasio BOPO) berpengaruh negatif terhadap kinerja perbankan. Hasil yang berbeda diungkapkan oleh Khalifaturofi'ah \& Nasution (2016) yang menyatakan bahwa efisiensi tidak berpengaruh terhadap kinerja perbankan.

Pengaruh antara variabel kecukupan modal dan kinerja perbankan juga memiliki hasil yang berbeda-beda seperti pada penelitian Thaibah \& Faisal (2020) yang menyatakan bahwa terdapat pengaruh positif terhadap kedua variabel ini sedangkan dalam penelitian Khalifaturofi'ah \& Nasution (2016) menemukan bahwa terdapat pengaruh negatif antara kedua variabel ini. Hasil ini juga berbeda dengan penelitian Purwoko \& Sudiyanto (2013), penelitian (Sutrisno, 2016) dan penelitian Oktaviani et al., (2019) yang mendapatkan hasil bahwa variabel kecukupan modal tidak berpengaruh terhadap kinerja perbankan.

Variabel konsentrasi pasar memiliki pengaruh positif terhadap kinerja perbankan berdasarkan hasil penelitian Saputri \& Kusumawardhani (2016) namun menurut Naylah \& Cahyaningratri (2020), terdapat pengaruh negatif antara kedua variabel ini. Hasil berbeda didapatkan oleh Nur Rianto Al Arif \& Awwaliyah (2019) yang menyatakan bahwa bahwa variabel konsentrasi pasar tidak berpengaruh terhadap kinerja perbankan.

Variabel pangsa pasar berpengaruh positif terhadap kinerja perbankan berdasarkan 
penelitian Naylah \& Cahyaningratri (2020), berbeda dengan hasil penelitian Saputri \& Kusumawardhani (2016) dan penelitian Nur Rianto Al Arif \& Awwaliyah (2019) yang mendapatkan bahwa pangsa pasar tidak berpengaruh terhadap kinerja perbankan.

\section{TINJAUAN PUSTAKA}

Variabel ukuran bank (SIZE) dalam penelitian ini diukur dengan logaritma natural (Ln) dari total assets. Secara khusus, dampak ukuran terhadap kinerja perbankan dibahas secara luas antar peneliti. Berbagai literatur telah menunjukkan bahwa hubungan antara ukuran bank dan kinerja bisa positif atau negatif. Kinerja perusahaan besar diharapkan lebih baik daripada perusahaan kecil karena memiliki kekuatan pasar dan skala ekonomi yang lebih luas. Perusahaan berskala besar akan memiliki kemampuan yang lebih tinggi dalam melakukan pengurangan biaya operasi. Pengurangan biaya ini menggambarkan efisiensi yang berarti kinerja perusahaan lebih baik sehingga profitabilitas meningkat. Di sisi lain, ukuran perusahaan juga dapat menyebabkan penurunan kinerjanya.

Perusahaan yang lebih besar cenderung memiliki tingkat diversifikasi produk dan pinjaman yang lebih tinggi daripada perusahaan berskala kecil. Selain potensi diversifikasi yang lebih tinggi, skala ekonomi yang dimiliki oleh perusahaan dengan ukuran yang lebih besar juga lebih luas. Diversifikasi tersebut mengurangi risiko dan skala ekonomi menggambarkan pada peningkatan efisiensi operasional. Sehingga dapat disimpulkan bahwa terdapat hubungan negatif antara ukuran perusahaan dan profitabilitas karena biaya agensi, proses birokrasi, dan alasan lain yang terkait dengan ukuran perusahaan (Mehrjardi, 2012).

Variabel efisiensi dalam penelitian ini diukur dengan menggunakan rasio Biaya Operasional terhadap Pendapatan Operasional (BOPO). Beberapa literatur yang ada mengungkapkan bahwa hubungan antara efisiesni dapat berpengaruh positif maupun negatif terhadap kinerja perbankan. Efisiensi biaya secara positif dan signifikan berpengaruh terhadap profitabilitas bank. Bank dengan tingkat efisiensi biaya yang tinggi memiliki profitabilitas yang lebih tinggi (Fang et al., 2019).

Tingkat efisiensi yang tinggi menggambarkan volume biaya yang lebih rendah sedangkan volume biaya yang lebih tinggi menunjukkan tingkat efisiensi yang rendah yang mengindikasikan bank tidak dapat mengendalikan dan mengelola biayanya dengan baik. Rasio Biaya Operasional terhadap Pendapatan Operasional (BOPO) yang tinggi (efisiensi rendah) mencerminkan kurangnya kemampuan Bank untuk melakukan pengurangan biaya operasi dan meningkatkan pendapatan operasionalnya sehingga mengakibatkan berkurangnya laba dihasilkan oleh Bank.

Di sisi lain, volume biaya operasi yang lebih tinggi (efisiensi rendah) akan berdampak negatif pada profitabilitas bank. Biaya operasional ini kemungkinan besar berasal dari gaji dan upah yang lebih tinggi. Menurut teori efisiensi, tingkat gaji yang lebih tinggi akan secara signifikan meningkatkan produktivitas karyawan yang juga akan berdampak pada peningkatan profitabilitas bank (Tan, 2016). Profitabilitas yang dihasilkan lebih besar jika dibandingkan dengan biaya yang telah dikeluarkan membayar gaji dan upah pegawai tersebut.

Capital Adequacy Ratio(CAR) digunakan sebagai proksi dari variabel kecukupan modal. Kecukupan modal merupakan porsi modal ekuitas lembaga keuangan yang diharapkan mampu menyerap potensi kerugian dan risiko dengan segala bentuknya seperti risiko kredit dan risiko pasar untuk memastikan keseimbangan yang berkelanjutan dan melindungi pemegang utang (Dang, 2011).

Secara umum, bank diwajibkan untuk memenuhi persyaratan minimum modal yang ditetapkan oleh otoritas pengawas. Pemenuhan kebutuhan modal yang besar dalam struktur permodalan bank merupakan elemen fundamental dari kecukupan modal. Seperti yang ditegaskan oleh Fama dan Jensen (1983), 
kurangnya disiplin struktur modal pada bank menyebabkan inefisiensi karena pemilik akan kehilangan kendali atas manajemen.

Kecukupan modal berdampak positif terhadap kinerja bank. Bank dengan modal yang lebih banyak dapat mengakses lebih banyak dana dengan biaya lebih murah sehingga dapat memberikan pinjaman dengan suku bunga rendah dan mengurangi kebutuhan pendanaan eksternal yang akan menghasilkan profitabilitas yang tinggi (Onuonga, 2014).

Selain faktor-faktor internal bank di atas yang berpengaruh terhadap kinerja bank, faktor industri yang merupakan struktur pasar juga memiliki pengaruh terhadap kinerja bank. Dalam penelitian ini variabel struktur pasar yang akan digunakan adalah konsentrasi pasar (market concentration) dan pangsa pasar (market share). Teori ekonomi menyatakan bahwa struktur pasar mempengaruhi kinerja perusahaan karena institusi yang lebih besar dapat memberikan layanan dengan biaya lebih rendah.

Hipotesis Structure Conduct Performance (SCP) berasumsi bahwa perilaku bank dipengaruhi oleh kekuatan pasar, sedangkan struktur pasar berperan penting dalam kinerja bank. Ide hipotesis ini didasarkan pada fakta bahwa dalam pasar yang lebih terkonsentrasi di mana saham-saham signifikan ditempati oleh beberapa bank, kondisi persaingan lebih rendah, sedangkan konsentrasi yang lebih tinggi mengarah pada kekuatan pasar yang lebih besar, dan peningkatan yang diakibatkan oleh perilaku kolusifmenyebabkan keuntungan yang lebih tinggi (Fu et al., 2014). Dengan demikian, SCP menggambarkan hubungan positif antara konsentrasi dan kinerja, melalui kemampuan untuk menawarkan suku bunga simpanan yang lebih rendah dan mengenakan suku bunga pinjaman yang lebih tinggi (González et al., 2019).

Struktur pasar industri diukur dengan tingkat konsentrasi dari industri tersebut yaitu dengan menggunakan indeks CR3 atau indeks konsentrasi 3 bank yang memiliki total aset terbesar. Ketiga aset tersebut akan dijumlahkan dan kemudian dibagi dengan keseluruhan total aset bank dalam industri.

Market Power Hypothesis berasumsi bahwa bank dengan pangsa pasar yang lebih tinggi memperoleh keuntungan yang lebih tinggi dengan menetapkan harga yang lebih tinggi. Bank dengan pangsa pasar yang kuat, dapat menggunakan saham dan ukurannya untuk mengeliminasi pesaing atau calon pesaing yang ada dengan mengurangi margin suku bunga sehingga dalam jangka pendek mengurangi pendapatan bunga dan mengurangi kinerja bank (Nouaili et al., 2015)in the past decades, numerous structural changes which have affected the banking industry in particular and the economy as whole. This paper studies the internal and external determinants of bank performance in Tunisia during the period after financial reforms. We used regression analysis and panel data technique with the linear model of Bourke (1989. Market Share atau pangsa pasar masing-masing bank diukur dengan rasio aset bank dibagi total aset industri perbankan.

\section{METODOLOGI}

Regresi data panel diterapkan untuk menganalisis data perbankan pada penelitian ini. Data yang digunakan adalah data 38 Bank Umum Konvesional yang terdaftar di Bursa Efek Indonesia yang memiliki data lengkap sesuai dengan variabel penelitian untuk periode tahun 2015 s.d. 2019.

Persamaan matematis dalam penelitian ini adalah:

$\mathrm{NIM}_{\mathrm{it}}=\beta_{0}+\beta_{1}$ Size $_{\mathrm{it}}+\beta_{2} \mathrm{BOPO}_{\mathrm{it}}+\beta_{3} \mathrm{CAR}_{\mathrm{it}}+$ $\beta_{4}$ Kon $_{\text {it }}+\beta_{5}$ Market $_{\text {it }}+\varepsilon_{\text {it }}$

$\mathrm{ROE}_{\mathrm{it}}=\beta_{0}+\beta_{1} \mathrm{Size}_{\mathrm{it}}+\beta_{2} \mathrm{BOPO}_{\mathrm{it}}+\beta_{3} \mathrm{CAR}_{\mathrm{it}}+$ $\beta_{4}$ Kon $_{\text {it }}+\beta_{5}$ Market $_{\text {it }}+\varepsilon_{\text {it }}$

dimana :

$\mathrm{NIM}_{\mathrm{it}}$ : Net Interest Margin

$\mathrm{ROE}_{\text {it }}$ : Return on Equity 
Size $_{\text {it }} \quad$ : Ukuran Bank

BOPO $_{\text {it }}$ : Biaya Operasional terhadap Pendapatan Operasional

$\mathrm{CAR}_{\mathrm{it}} \quad$ : Capital Adequacy Ratio

Kon $_{\text {it }} \quad$ : Konsentrasi Pasar (CR3)

Market $_{\text {it }}$ : Pangsa Pasar

\section{Pemilihan Model (Teknik Estimasi) Regresi Data Panel}

Regresidatapaneldilakukanmenggunakan tiga model yaitu model common effects, fixed effects, dan random effects. Model common effects berasumsi bahwa tidak dapat diketahui perbedaan baik antar individu maupun antar waktu. Model fixed effects mengasumsikan adanya perbedaan antar individu dan antar waktu secara langsung. Model random effects berasumsi bahwa intersep dan kontanta disebabkan oleh residual/error sebagai akibat perbedaan antar unit dan antar periode waktu yang terjadi secara random. (Sriyana, 2014). Pemilihan model dilakukan menggunakan beberapa tahapan.

Pemilihan model terbaik di antara metode fixed effect dan metode common effect dilakukan dengan menggunakan Uji Chow. Apabila fixed effect terpilih sebagai metode terbaik, maka dilakukan Uji Hausman untuk memilih antara metode fixed effect dan metode random effect.
Apabila metode Fixed Effect telah terpillih sebanyak dua kali dalam Uji Chow maupun Uji Hausman, maka pemilihan model tidak dilanjutkan ke Uji Lagrange Multiplier. Namun, apabila pada saat dilakukan Uji Hausman yang terpilih adalah metode random effec, maka untuk memilih model terbaik antara random effect dan model common effect diperlukan Uji Lagrange Multiplier.

\section{Uji Kelayakan Model Regresi Data Panel}

\section{a. Uji Hipotesis}

Uji-F dilakukan untuk menguji apakah model yang dipilih dalam penelitian mampu untuk mengintepretasikan pengaruh variabel bebas terhadap variabel terikat secara bersamasama. Uji-t dilakukan untuk menguji pengaruh antara variabel bebas secara individu terhadap variabel terikat.

b. Koefisien Determinasi (R-Squares)

Nilai Koefisien Determinasi mencerminkan seberapa besar pengaruh variabel bebas terhadap variabel terikat.

\section{HASIL DAN PEMBAHASAN}

\section{Hasil Penelitian}

1. Pemilihan Model Regresi Data Panel

a. Uji Chow

Tabel 1 Uji Chow

\begin{tabular}{lcccccc}
\hline & \multicolumn{3}{c}{ Model 1 } & \multicolumn{3}{c}{ Model 2 } \\
\hline Effects Test & Statistic & d.f. & Prob. & Statistic & d.f. & Prob. \\
Cross-section F & 26.067923 & $(38,151)$ & 0.0000 & 5.367964 & $(38,151)$ & 0.0000 \\
Cross-section Chi-square & 394.463481 & 38 & 0.0000 & 166.683866 & 38 & 0.0000 \\
\hline
\end{tabular}

Nilai Probabilitas pada Cross-section berdasarkan Chow Test, model Fixed Effect $\mathrm{F}<\alpha$ yaitu sebesar $0,0000<0.05$, yaitu lebih tepat dibandingkan model Common sebesar $0,0000<0,05$, maka dapat disimpulkan Effect. 
b. Uji Hausman

Tabel 2 Uji Hausman

\begin{tabular}{lcccccc}
\hline & \multicolumn{3}{c}{ Model 1 } & \multicolumn{3}{c}{ Model 2 } \\
\hline Test Summary & Chi-Sq. Statistic & Chi-Sq. d.f. & Prob. & Chi-Sq. Statistic & Chi-Sq. d.f. & Prob. \\
\hline Cross-section random & 23.087110 & 5 & 0.0003 & 7.571974 & 5 & 0.1815 \\
\hline
\end{tabular}

Nilai probabilitas $<\alpha$ yaitu sebanyak 2 (dua) kali. Dengan demikian sebesar $0.0000<0.05$, maka dapat disimpulkan pemilihan selanjutnya dengan menggunakan berdasarkan Hausman Test, model Fixed Lagrange Multiplier tidak perlu dilakukan Effect lebih tepat dibandingkan model Random karena model Fixed Effect merupakan model Effect. Model Fixed Effect telah terpilih terbaik untuk menjawab tujuan penelitian.

\section{Uji Kelayakan (Goodness of Fit) Model Regresi Data Panel}

Tabel 3 Hasil Regresi Data Panel

\begin{tabular}{ccccc}
\hline & \multicolumn{2}{c}{ Model 1 } & \multicolumn{2}{c}{ Model 2 } \\
& Dependent Variable: NIM & \multicolumn{2}{c}{ Dependent Variable: ROE } \\
\hline Variable & t-Statistic & Prob. & t-Statistic & Prob. \\
\hline C & 4.264935 & 0.0000 & 3.021186 & 0.0030 \\
SIZE & -4.155678 & $0.0001^{* *}$ & -1.684648 & $0.0941^{*}$ \\
BOPO & -2.857519 & $0.0049^{* *}$ & -23.04153 & $0.0000^{* *}$ \\
CAR & -0.595585 & 0.5523 & 1.235472 & 0.2186 \\
KON & 0.139013 & 0.8896 & -1.113339 & 0.2673 \\
MARKET & 3.547984 & $0.0005 * *$ & 1.207252 & 0.2292 \\
\hline R-squared & \multicolumn{2}{c}{ Effects Specification } & & 0.930493 \\
Adjusted R-squared & 0.900339 & & 0.910699 \\
F-statistic & 0.871959 & & 47.01017 \\
Prob(F-statistic) & 31.72426 & & 0.000000 \\
\hline & $*$ & Significance at level 10\%** Significance at level 5\% &
\end{tabular}

Nilai probabilitas $\mathrm{F}$ hitung untuk kedua model dalam penelitian ini sebesar 0,000000 lebih kecil dari tingkat signifikasi $\alpha=5 \%$ maka dapat simpulkan bahwa variabel ukuran bank (SIZE), efisiensi (BOPO), kecukupan modal (CAR), konsentrasi pasar (KON), dan pangsa pasar (MARKET) secara bersama-sama berpengaruh terhadap kinerja perbankan baik diukur dengan Net Interest Margin (NIM) maupun diukur dengan Return on Equity (ROE).

Dari hasil regresi data panel untuk model 1 didapatkan bahwa ukuran bank (SIZE), efisiensi (BOPO), dan pangsa pasar
(MARKET) memperlihatkan hasil yang signifikan dengan tingkat signifikansi di bawah 0,05 , yang berarti bahwa ketiga variabel ini memiliki pengaruh terhadap kinerja perbankan yang diukur dengan Net Interest Margin (NIM). Variabel kecukupan modal (CAR) dan konsentrasi pasar (KON) memperlihatkan hasil bahawa kedua variabel ini tidak berpengaruh terhadap Net Interest Margin (NIM).

Hasil regresi data panel untuk model 2 didapatkan bahwa ukuran bank (SIZE) memperlihatkan hasil yang signifikan dengan tingkat signifikansi di bawah 0,1 sedangkan 
efisiensi (BOPO), memperlihatkan hasil yang signifikan dengan tingkat signifikansi di bawah 0,05 , yang berarti bahwa kedua variabel ini memiliki pengaruh terhadap kinerja perbankan yang diukur dengan Return on Equity (ROE). Variabel kecukupan modal (CAR), konsentrasi pasar (KON), dan pangsa pasar (MARKET) memperlihatkan hasil yang tidak signifikan yang berarti bahwa variabelvariabel tersebut tidak berpengaruh terhadap Return on Equity (ROE).

Berdasarkan hasil regresi data panel, besarnya koefisien determinasi (R Square) untuk model 1 dalam penelitian ini adalah sebesar 0,9003 atau 90,03\%. Hal ini berarti 90,03\% variabel Net Interest Margin (NIM) dapat dijelaskan oleh variasi dari kelima variabel independen yaitu ukuran bank (SIZE), efisiensi (BOPO), kecukupan modal (CAR), konsentrasi pasar (KON), dan pangsa pasar (MARKET) sedangkan sisanya 9,97\% dijelaskan oleh variabel lain di luar model.

Hasil regresi data panel untuk model 2 menunjukkan besarnya koefisien determinasi (R Square) sebesar 0,9305 atau 93,05\%. Hal ini berarti 93,05\% variabel Return on Equity (ROE) dapat dijelaskan oleh variasi dari kelima variabel independen yaitu ukuran bank (SIZE), efisiensi (BOPO), kecukupan modal (CAR), konsentrasi pasar (KON), dan pangsa pasar (MARKET) sedangkan sisanya 6,95\% dijelaskan oleh variabel lain di luar model.

\section{Pembahasan}

Penelitian ini mendapatkan hasil bahwa varibael ukuran bank memiliki pengaruh negatif terhadap kinerja perbankan pada kedua model dalam penelitian ini. Pengaruh negatif ini secara empiris menunjukkan bahwa semakin besar suatu bank, semakin sulit untuk dikelola (Dietrich \& Wanzenried, 2014). Pengelolaan yang sulit ini dapat mempengaruhi kinerja bank yang. Penelitian ini mendapatkan hasil yang berbeda dengan penelitian Hendrawan \& Lestari (2017) dan penelitian Damayanti \& Savitri (2012) yang menyatakan bahwa ukuran bank berpengaruh positif terhadap profitabilitas serta penelitian Yusuf (2017) dan penelitian Oktaviani et al., (2019) yang mendapatkan hasil bahwa ukuran bank tidak berpengaruh terhadap profitabilitas perbankan.

Variabel tingkat efisiensi yang dihitung dengan perbandingan biaya operasional dengan pendapatan operasionalnya memiliki pengaruh yang negatif terhadap kinerja perbankan (profitabilitas). Penelitian ini memiliki hasil yang sama dengan penelitian Thaibah \& Faisal (2020) dan penelitian Haryati \& Widyarti (2016). Hal ini mengindikasikan bahwa apabila tingkat efisiensi rendah yang ditandai dengan rasio BOPO yang tinggi, maka dapat menyebabkan penurunan pada profitabilitas ataupun sebaliknya jika tingkat efisiensi tinggi maka dapat menyebabkan peningkatan pada profitabilitas (Hefferman \& $\mathrm{Fu}, 2010)$. Penelitian ini memiliki perbedaan hasil dengan Khalifaturofi'ah \& Nasution (2016) yang menyatakan bahwa efisiensi tidak berpengaruh terhadap kinerja perbankan.

Variabel kecukupan modal tidak memiliki pengaruh terhadap kinerja perbankan untuk kedua model dalam penelitian ini. Penelitian ini mendukung hasil penelitian Oktaviani et al., (2019) dan penelitian Purwoko \& Sudiyanto (2013). Kecukupan modal yang dimiliki bank tidak dapat meningkatkan profitabilitas apabila dana tersebut tidak digunakan untuk investasi. Rasio CAR yang melebihi dari ketentuan minimumnya dapat menunjukkan penyaluran dana yang tidak tepat.

Kecukupan modal tidak penting dalam menentukan profitabilitas bank karena sebagian besar bank yang memiliki profitabilitas tinggi tidak membiayai operasinya untuk instrumen hutang atau ekuitas (Kagecha, 2014). Bank dengan cukup modal tidak mampu serta serta gagal mendukung kebijakan rekapitalisasi regulator (Bhattarai, 2014).

Hasil penelitian ini berbeda dengan Thaibah \& Faisal (2020) yang menyatakan bahwa variabel kecukupan modal berpengaruh positif terhadap kinerja perbankan serta memiliki hasil berbeda pula dengan 
Khalifaturofi'ah \& Nasution (2016) yang menyatakan bahwa terdapat pengaruh negatif antara kedua variabel ini.

Variabel konsentrasi pasar tidak berpengaruh terhadap kinerja perbankan untuk kedua model penelitian ini. Penelitian ini mendukung hasil penelitian Nur Rianto Al Arif \& Awwaliyah (2019). Structure Conduct Performance (SCP) Hypothesis tidak berlaku di bank negara berkembang. Bank di negara berkembang kurang efisien di pasar yang lebih terkonsentrasi karena tingkat pengembangan sistem keuangan terbatas, beberapa entitas beroperasi di pasar dengan tingkat teknologi rendah, ketidakpastian yang tinggi, dan biaya operasional yang tinggi (González et al., 2019).

Penelitian ini memiliki hasil berbeda dengan penelitian Suhel (2015) dan penelitian Saputri \& Kusumawardhani (2016) yang menyatakan bahwa variabel konsentrasi pasar berpengaruh positif dan signifikan terhadap kinerja perbankan.

Variabel pangsa pasar (market share) berpengaruh positif terhadap kinerja perbankan (pada model 1) dan tidak berpengaruh pada kinerja perbankan (pada model 2). Hasil yang menunjukkan pengaruh positif dan signifikan mendukung Relative Market Power (RMP) Hypothesis. Bank dengan pangsa pasar yang lebih tinggi dapat menggunakan kekuatan pasarnya untuk memperoleh kinerja yang lebih tinggi pula. Bank dengan pangsa pasar yang luas memiliki skala dan cakupan ekonomi yang luas serta memiliki daya tarik pelanggan berdasarkan kualitas layanan mereka, distribusi cabang yang besar, dan merk yang dikenal oleh masyarakat. Semua elemen ini dapat mempengaruhi harga dan biaya operasi sehingga meningkatkan kinerja bank dengan pangsa pasar yang lebih tinggi. Pada model 2, variabel market share tidak berpengaruh terhadap kinerja perbankan (ROE). Penelitian ini mendukung hasil penelitian Saputri \& Kusumawardhani (2016). Pangsa pasar tidak akan mempengaruhi kemampuan perusahaan untuk menghasilkan laba dari investasi pemegang saham di perusahaan tersebut.

\section{KESIMPULAN}

Hasil penelitian ini mendapatkan hasil bahwa variabel ukuran bank dan efisiensi (BOPO) memiliki pengaruh negatif dan signifikan terhadap kinerja perbankan. Variabel kecukupan modal dan konsentrasi padar tidak berpengaruh terhadap kinerja perbankan. Sedangkan variabel pangsa pasar memiliki pengaruh positif dan signifikan terhadap kinerja perbankan yang diukur dengan Net Interest Margin namun tidak berpengaruh terhadap kinerja perbankan yang diukur dengan Return on Equity.

Studi ini memiliki beberapa keterbatasan. Pertama, jangka waktu studi bisa lebih lama untuk mengevaluasi apakah perubahan kondisi akan mempengaruhi hasil. Penelitian selanjutnya dapat mempertimbangkan untuk menganalisis pasar lain, dengan kondisi yang serupa atau berbeda untuk membandingkan hasil. Selain itu, akan lebih menarik untuk memasukkan bank umum syariah maupun bank perkreditan rakyat dalam analisa, dan menggunakan ukuran lain untuk variabel struktur pasar.

\section{DAFTAR PUSTAKA}

Bhattarai, Y. R. (2014). the Effect of Credit Risk on Nepalese Commercial Banks. NRB Economic Review, vol28-1(1), 24. https://nrb.org.np/ecorev/articles/vol28-1_art3.pdf

Damayanti, P., \& Savitri, D. A. M. (2012). Analisis pengaruh ukuran (size), capital adequacy ratio (CAR), pertumbuhan deposit, loan to deposit ratio (LDR), terhadap profitabilitas perbankan go public di indonesia tahun 2005-2009 (studi empiris perusahaan perbanka yang terdaftar di BEI). Jurnal Ilmiah Manajemen Dan Akuntansi Terapan (JIMAT), 3(2), 
$45-54$.

Dang, U. (2011). the Camel Rating System in Banking Supervision. Arcada University of Applied Sciences.

Dietrich, A., \& Wanzenried, G. (2014). The determinants of commercial banking profitability in low-, middle-, and high-income countries. Quarterly Review of Economics and Finance, 54(3), 337-354. https://doi.org/10.1016/j.qref.2014.03.001

Fama, E. F., \& Jensen, M. C. (1983). Separation of ownership and control. The journal of law and Economics, 26(2), 301-325.

Fang, J., Lau, C. K. M., Lu, Z., Tan, Y., \& Zhang, H. (2019). Bank performance in China: A Perspective from Bank efficiency, risk-taking and market competition. Pacific Basin Finance Journal, 56, 290-309. https://doi.org/10.1016/j.pacfin.2019.06.011

González, L. O., Razia, A., Búa, M. V., \& Sestayo, R. L. (2019). Market structure, performance, and efficiency: Evidence from the MENA banking sector. International Review of Economics and Finance, 64, 84-101. https://doi.org/10.1016/j.iref.2019.05.013

Haryati, R., \& Widyarti, E. T. (2016). Pengaruh Leverage, Size, NPL, BOPO dan LDR Terhadap Kinerja Keuangan Bank (Studi Pada Bank Umum Konvensional Yang Terdaftar Di Bursa Efek Indonesia Periode 2010-2014). Diponegoro Journal Of Management, 5(3), 1-13. http://ejournal-s1.undip.ac.id/index.php/dbr

Hendrawan, Y. P., \& Lestari, H. S. (2017). Faktor - Faktor Penentu Profitabilitas Bank Umum Yang Terdaftar Di Bursa Efek Indonesia (Bei). Jurnal Manajemen Dan Pemasaran Jasa, 9(1), 99. https://doi.org/10.25105/jmpj.v9i1.1413

Kagecha, P. K. (2014). Bank performance: Does bank size matter. University of Nairobi.

Khalifaturofi'ah, S. O., \& Nasution, Z. (2016). Analisis Faktor-Faktor yang. Jurnal Perbankan Syariah, 1(2), 42-64.

Mehrjardi, S. M. (2012). Size and Profitability of Banks in Kenya. Business Administration University of Nairobi.

Naylah, M., \& Cahyaningratri, C. (2020). The Influence of Market Structure in Indonesian Banking Performance. Jejak, 13(1), 120-134. https://doi.org/10.15294/jejak.v13i1.21458

Nouaili, M., Abaoub, E., \& Ochi, A. (2015). International Journal of Economics and Financial Issues The Determinants of Banking Performance in Front of Financial Changes: Case of Trade Banks in Tunisia. International Journal of Economics and Financial Issues, 5(2), 410-417. http:www.econjournals.com

Nur Rianto Al Arif, M., \& Awwaliyah, T. B. (2019). Market Share, Concentration Ratio and Profitability: Evidence from Indonesian Islamic Banking Industry. Journal of Central Banking Theory and Practice, 8(2), 189-201. https://doi.org/10.2478/jcbtp-2019-0020

OJK. (2019). Resume Peraturan Ojk Bidang Perbankan Yang Masing Berlaku Pada Tahun 2018. https://www.ojk.go.id/id/kanal/perbankan/data-dan-statistik/booklet-perbankanindonesia/Documents/Pages/Booklet-Perbankan-Indonesia-2019/Booklet Perbankan Indonesia 2019 Long Version.pdf

Oktaviani, S., Suyono, \& Mujiono. (2019). Analysis The Effect Of CAR, BOPO, LDR, NIM And Firm Size On Profitability Of Banks Listed On IDX Period 2012-2017. Bilancia Jurnal Ilmiah Akuntansi, 3(2), 146-157.

Onuonga, S. M. (2014). The Analysis of Profitability ofKenyàs Top Six Commercial Banks: 


\section{ISSN: 1410-4571, E-ISSN: 2541-2604}

Internal Factor Analysis. American International Journal of Social Science, 3(5), 94-103. http://www.aijssnet.com/journals/Vol_3_No_5_October_2014/10.pdf

Paradi, J. C., \& Zhu, H. (2013). A survey on bank branch efficiency and performance research with data envelopment analysis. Omega (United Kingdom), 41(1), 61-79. https://doi. org/10.1016/j.omega.2011.08.010

Purwoko, D., \& Sudiyanto, B. (2013). Faktor-faktor yang Mempengaruhi Kinerja Bank (Studi Empirik Pada Industri Perbankan di Bursa Efek Indonesia). Jurnal Bisnis Dan Ekonomi, 20(1), 25-39.

Roghanian, P., Rasli, A., \& Gheysari, H. (2012). Productivity Through Effectiveness and Efficiency in the Banking Industry. Procedia - Social and Behavioral Sciences, 40, 550556. https://doi.org/10.1016/j.sbspro.2012.03.229

Saputri, M. R., \& Kusumawardhani, A. (2016). Pengaruh konsentrasi pasar, pangsa pasar, dan rasio keuangan terhadap kinerja keuangan bank umum swasta nasional devisa di Indonesia tahun 2010-2014. Jurnal Manajemen, 5(3), 1-11. https://ejournal3.undip.ac.id/ index.php/djom/article/view/14204

Sriyana, J. (2014). Metode Regresi Data Panel (1st ed.). Ekonisia.

Stephani, R., Adenan, M., \& Hanim, A. (2017). Analisis Pengaruh Rasio Keuangan Terhadap Kinerja Bank Umum di Indonesia ( Analysis of Financial Ratio Influenca on the Commercial Bank in Indonesia ). E-Journal Ekonomi Bisnis Dan Akuntansi, IV(2), 192 195.

Suhel. (2015). Payment systems: principles, practice, and improvements. Jurnal Ekonomi Pembangunan, 13(1), 1-9.

Sutrisno. (2016). The Risk, Efficiency And Bank Performances Emphirical Study Of Convensional Banks In Indonesia. Jurnal Ilmiah Akuntansi Dan Bisnis, 11(2), 111-116.

Tan, Y. (2016). The impacts of risk and competition on bank profitability in China. Journal of International Financial Markets, Institutions and Money, 40, 85-110. https://doi. org/10.1016/j.intfin.2015.09.003

Thaibah, \& Faisal. (2020). Pengaruh Kecukupan Modal, Ukuran Bank, Biaya Operasional Dan Likuiditas Terhadap Kinerja Keuangan Perbankan Yang Terdaftar Di Bursa Efek Indonesia. Jurnal Ilmiah Mahasiswa Ekonomi Manajemen, 5(2), 294-309.

Yusuf, M. (2017). Dampak Indikator Rasio Keuangan terhadap Profitabilitas Bank Umum Syariah di Indonesia. Jurnal Keuangan Dan Perbankan : ISSN 1829-9865, 13(2), 141151. 